\title{
The Impact of Corporate Social Responsibility Initiatives on Rural Community Development: The Case of TITAN - Sharrcem in Kosovo Haziz Vila ${ }^{1}$, Nikolaos Sklavounos ${ }^{1}$, Evangelos Vergos ${ }^{1}$, Konstantinos Rotsios ${ }^{1}$,
and Hysen Shabanaj ${ }^{2}$
}

${ }^{1}$ Perrotis College, American Farm School, Thessaloniki, Greece

${ }^{2}$ Laboratory for Business Activities (LAB), Hani i Elezit, Kosovo

\section{Abstract}

Corporate Social Responsibility (CSR) has become an integral part of firms' strategies in their effort to increase their positive impact on society. This study investigates the impact of a CSR initiative, known as "The LAB Project", implemented by the TITAN -- Sharrcem Company, on the rural community of Hani I Elezit in Kosovo. The LAB project aims to support the establishment and operation of agricultural and food related start-ups and, most importantly, to ensure their sustainability. The sample

Corresponding Author: Nikolaos Sklavounos

Received: 17 November 2019 Accepted: 6 January 2019

Published: 12 January 2020

Publishing services provided by Knowledge E

(c) Haziz Vila et al. This article is distributed under the terms of the Creative Commons

Attribution License, which permits unrestricted use and redistribution provided that the original author and source are credited.

Selection and Peer-review under the responsibility of the EBEEC Conference Committee.

\section{G OPEN ACCESS} of the study consists of 174 area residents. This research examines local residents' perceptions about a) the TITAN-Sharrcem operations in the area, b) the LAB project's main contribution to the local community, c) the project's overall performance, d) the profitability of the start-ups created by the project, and e) the project's effect on the community's quality of life. Overall, the results reveal that the project has set the foundation for the community's sustainable development. To the best of the authors' knowledge, this is the first research on the effect of such initiatives in the region.

Keywords: Corporate Social Responsibility, Rural Entrepreneurship, Community Development

JEL CLASSIFICATION: M14 Corporate Culture - Diversity - Social Responsibility

\section{Introduction}

Corporate Social Responsibility (CSR) has become a fundamental part of major business organizations globally. CSR initiatives have recently received increasing attention due to a number of incentives related to regulations, consumers' awareness, and brand imaging that significantly affect their sustainability [1]. To that end, there is an ongoing debate over the meaning of CSR in the business world. More specifically, CSR practices have become a priority for high profile companies worldwide as past research has shown its overall positive impact on organizations [2]. For example, over 3,500 companies have been part of the Reporting Initiative and produced approximately 8,000 CSR reports [3]. 
According to the same researchers, "In a 2008 Economist online survey of $1192 \mathrm{global}$ executives an estimated 55 percent reported that their companies gave high priority to corporate responsibility" [3].

The above demonstrates that CSR has become a top priority for organizations as they have recognized the short and long-term advantages it can offer through a strong impact on issues faced by local and global communities. Community development is the most important among the three categories of CSR initiatives, the other two being socially responsible production processes and relations with the employees [4].

CSR initiatives should be reported by firms and shared with their various stakeholders [5]. Such reports are both necessary and beneficial to the organizations in the sense that they display progress made and areas for improvement. At the same time, these reports can serve as an effective tool for enhancing their reputation.

The aim of this paper is to present the success story of the LAB Project, a nongovernmental organization created by Sharrcem Company (subsidiary of TITAN Group), under the auspices of a non-for-profit Foundation created and governed by Sharrcem, and in the framework of the CSR activities of Sharrcem and TITAN. The project's main focus is the sustainable development of the community of Hani I Elezit in Kosovo and shows the extent to which the project has improved the lives of the HIE residents. Further, the research illustrates how firms can implement similar CSR initiatives to build a stronger and more sustainable relationship with the community while simultaneously improve their overall public image. Additionally, the study demonstrates how CSR practices can lead to sustainable community development, thought the production of quality local products.

The aims and objectives of this research will be achieved by empirically investigating the following five research questions: What are the HIE residents' perceptions about a) the TITAN-Sharrcem operations in the area?, b) the LAB project's main contribution to the local community?, c) the LAB project's overall performance?, d) the profitability of the start-ups created by the LAB project?, and e) the LAB project's effect on the community's quality of life?

\section{Literature Review}

\subsection{CSR and company reputation}

The European Commission [5] defines CSR as "a concept whereby companies integrate social and environmental concerns in their business operations and in their interaction 
with their stakeholders on a voluntary basis". Thus, according to CSR principles, in addition to profit generating activities, organizations should treat local communities and societies in a respectful manner. The organizations' environmental responsibility has an impact on consumers as well as communities and, thus, should be evaluated on their level of environmental and social responsibility [6]. Isa [6] characterizes CSR as a firm's approach that contributes to its long-term sustainable development and growth [7]. The increased understanding of the positive impact of CSR initiatives on consumer attitudes leads companies to embrace such strategies despite substantial financial costs [8].

Abdolvand and Charsetad [9] suggest that consumers seek companies which have adopted effective CSR strategies and have embed them into the core values and routines of the organization. Similarly, according to Fatma et al. [10], CSR programs often result in the improvement of company brand name awareness and reputation. Researchers have argued that the improved financial results of socially responsible enterprises can often be attributed to better reputation and customer loyalty [11]. Likewise, companies with a negative or deteriorating image can improve consumer perceptions of them with an effective CSR plan [12]. Such examples have been documented in existing relevant literature $[13,14]$.

Despite all of the above, there is sometimes criticism regarding company motives behind CSR implementation. Šontaitè-Petkevičienè [15] suggests that some firms engage in CSR initiatives only to enhance their reputation and are not driven by the need to "give back to society" or any philanthropic intentions. In any case, Banerjee [16] notes that major global issues cannot be efficiently addressed by large multinational companies whose main scope is to meet their strategic financial goals. Smaller companies primarily address local issues through their CSR activities [17].

\subsection{TITAN-Sharrcem engagement in the community of Hani I Elezit}

Titan Cement Company S.A. was founded in 1902 in Athens, Greece. According to TITAN Integrated Annual Report 2018 [18], TITAN is an international cement and building materials producer with a history of more than 115 years. The Group business activities include the production, transportation, and distribution of cement, concrete, aggregates, fly ash, mortars, and other building materials. TITAN Group has operations in 14 countries under four geographic regions: USA, Greece and Western Europe, Southeastern Europe, and Eastern Mediterranean. In 2018 TITAN generated a consolidated turnover of $€ 1490.1$ million and employed a total of 5,365 people [18]. In 2010 Titan purchased Sharrcem, 
a cement plant in Hani I Elezit, and a distinctive aspect of TITAN presence in Kosovo has been related to their strong involvement with the local community. According to the firm's Integrated Annual Report [18], "TITAN Group aims to grow as a multi-regional, vertically-integrated cement producer, combining entrepreneurial spirit and operational excellence with respect for people, society and the environment." One year after the acquisition in Kosovo, the company started implementing CSR activities and became a founding member of the Kosovo CSR Network. From the beginning company efforts focused on increasing local population awareness on issues regarding welfare, health, safety, and the environment. In addition to several CSR related activities, the company initiated a waste water treatment project in Hani I Elezit in 2013 [19].

\subsection{The LAB Project}

As early as 2011, TITAN initiated a thorough mapping of previous published studies, and an investigation of local conditions for assessing the 'base line' of basic economic indicators and potential growth drivers for the local population. According to Vergos and Shabanaj [20], the Sharrcem cement plant, which is located in the town of Hani I Elezit next to Kosovo-North Macedonia border (founded in 1937 as a state-owned company), is one of the largest employers in Kosovo and the only large employee for the local community. No other significant economic activity exists for the approximate 10,000 residents in the area, who are plagued by $50 \%$ poverty, high unemployment reaching 70\% especially among young population, high migration rates (mostly 'brain drain', and without always tracking on legalities) and the low educational opportunities [21]. The income of the rest of private sector is negligible, $34 \%$ of local population lives below the poverty threshold, with primitive health, sanitary, road and safety infrastructure, and practically zero vocational education offered. The annual budget of the municipality of 10,000 citizens is less than $€ 2.0 \mathrm{~m}$. It is clearly a vulnerable society.

However, the local population has the ability to explore the numerous growth opportunities. Due to the atrocities and war conditions which escalated in 1998-1999, natural resources in the area were not exploited to their full potential over the last 2-3 decades, and had been to a large extend, underutilized. Under the light of the above, TITAN's initiative to create LAB with the mission to offer agro-food entrepreneurial opportunities, was a crucial step towards ensuring the sustainability of the local community. The Project was designed to offer alternative income generation through the application of corporate social responsibility schemes [22]. Upon inception of the Project, the management of the $\mathrm{BU}$ invited various stakeholders (on national and international level) to participate, 
and a Board of Directors was formed. The involvement of local stakeholders is rather important as companies should consider the stakeholders' perceptions on the issues CSR activities should address [23].

In addition, an IFC Advisory Arm was engaged between 2012-2013, to establish governance mechanisms. Additionally, the Sharrcem team assumed the role of contributor and sponsor (with human resources and expertise), offering administrative support to $\mathrm{LAB}$, along with the municipality, where its input aimed at strengthening the relationship between the involved parties.

In February 2014 Sharrcem established the non-for-profit organization called "Laboratory for Business Activities" and the LAB Project was initiated [24]. Its objective was "to continue being a promoter in creating new values in different sub sectors in agroforestry and providing support in formal education and technical assistance" for citizens of Hani I Elezit [25]. Additionally, the Project provides today training and consultancy services, as education opportunities to members of the local community. The aim is to provide conditions for self-employment, and income generation opportunities for the local population.

Initially (2014) 19 farmers in total were selected for participating in the project as beneficiaries. Their selection was based on criteria such as financial situation, household composition, land and land slope farming experience, etc., in order to ensure the maximum impact on the community [24]. The overall outcome has been very positive and a feeling of trust towards the project has developed on the participants' part. A number of activities such as small fruit, greenhouse, beekeeping and mushroom production, in addition to livestock and medical herbs production, were introduced.

In 2015, the operation of 37 newly established start-ups resulted in the creation of the equivalent of 86.7 working days per farm [26]. As a result of particularly positive and promising outcomes in the first year, project funds available were increased by over 52\%. In 2016, the LAB continued to support economic activities (start-ups) from the previous years and added several new ones. In the same year, the farmers' total workload created was equivalent to 2200 working days (9.7 full-time jobs), out of which $68 \%$ were performed by males and $32 \%$ by females [27].

The project has had a significant impact on community development. A culture of entrepreneurship has developed and the creation of new small enterprises has reduced unemployment in the area. As a result of the 78 newly established farms/enterprises in the town, the quantity of production, as well as the farmers' income, has increased substantially. Local farmers began supplying fruits and vegetables to the Hani I Elezit market as well as to markets in the surrounding communities. Another major impact 
is the creation of employment opportunities for local women. In 2017, there were nine women among the project's beneficiaries [28]. This is considerably significant considering that reports of the Kosovo Institute of Statistics [21] indicate a notable gender inequality in terms of employment.

During the 2014-2018 period a total of $748,450 €$ have been invested in the sector. The fifth year of investment closed with the establishment of 82 start--ups in 12 sub-agroforestry sectors: Greenhouse, Small Fruits (raspberries and strawberries), Beekeeping, Mushrooms, Nuts orchard, Livestock (milk production and milk processing), Vineyards, Forestry -- Wood biomass for energy production, Poultry -- egg production, and Medicinal and Aromatic Herbs [25]. In 2018, the LAB project "was increasingly involved in assisting all beneficiaries in implementation of food safety standards in order to create new opportunities to gain access to better market in region and EU, through traders or export-oriented collection centers" [25].

The project's overall objective is the long-term impact on community agricultural and overall economic development. In this context, the industry's CSR initiatives do not aim simply on improving its public image but on building a long-lasting relationship creating synergies between local community and business. In addition to economic returns, project benefits include community empowerment, engagement, and employment opportunities for women and young adults. Finally, it should be noted that project success facilitated the efforts to attract funding from other sources, such as a grant from the United States Agency for International Development (USAID) supporting 15 farmers in the community.

\section{Methodology and Sample}

The present study examines local resident perceptions of a) TITAN-Sharrcem operations in the area, b) the project's contribution to local community, c) the project's overall performance, d) the profitability of the start-ups created by the project, and e) the project's effect on the community's quality of life. In this research, we adopt the approach of Ismail et al. [29] that, "Community Development refers to the delivery of goods and services and financial provisions to the community by an external organization, i.e. aimed at improving the living standards of the community".

Quantitative research was used to investigate the effectiveness of the CSR strategies of TITAN-Sharrcem in the region of Hani I Elezit as perceived by local residents. According to Wisdom et al. [30], with this approach the information collected can be analyzed and presented in numerical values. Following meetings with the firm's executives, a 
questionnaire was designed. In order to test its clarity and to ensure that the questions are appropriate and easily comprehended [31] the input of three researchers with experience in this field was taken under consideration. Following their feedback and suggestions the final version of the questionnaire was developed in English and then translated into the native language of respondents (Albanian). Questionnaires were used to facilitate efficient collection of primary data [32]. Questionnaires are regarded as an important tool for the collection of necessary primary data when the researcher fully understands how to measure the variables under investigation [33].

The questionnaire was compiled first in 2017 and contained a total of 18 themes, consisting mainly of multiple-choice questions and questions which employed a 5-point Likert scale (from Strongly Disagree to Strongly Agree) related to TITAN-Sharrcem CSR activities and the LAB Project. The survey was rolled-out in the spring of 2017. The Likert scale was used because it provides respondents with flexibility in their evaluation of a given subject [34]. In addition, a cover letter explained the aim of the project and assured respondents that their responses would be kept anonymous and confidential. The target population in this research was the local community of Hani I Elezit. Responses were collected through online surveys as well as hard copies for respondents with no internet access. A total of 174 usable questionnaires were gathered in a four-week period. This represents over 3\% of the city's adult (over 19-years-old) population of 5725 [35].

\section{Results}

From the 174 respondents, 63\% were male and 37\% were female. The fact that the perceptions of the female population are presented in this research is rather important considering that gender inequality is a main challenge facing the country today [36]. The majority (32\%) are in the age group of $21-30$ years and $28 \%$ in the $31-40$ age group, followed by $20 \%$ in age group of over 50 years. Moreover, $17 \%$ of the respondents are in the $41-50$ years category and 3\% are under 20 years old (Figure 1).

Over $50 \%$ of the respondents have a High School/Secondary Degree, followed by $28 \%$ who report to have a Graduate Degree. A total of $21 \%$ of respondents were undergraduate students (Figure 2).

Respondents were given 5 options to describe their perceptions regarding TITANSharrcem operations. A total of $40 \%$ of them replied that the LAB Project is the first thing that comes to their minds when they think about the company. The second most popular answer (19\%) was "all of the above", (LAB Project, Community Support, Environmental Pollution, and Decrease of Unemployment) followed by Decrease of 


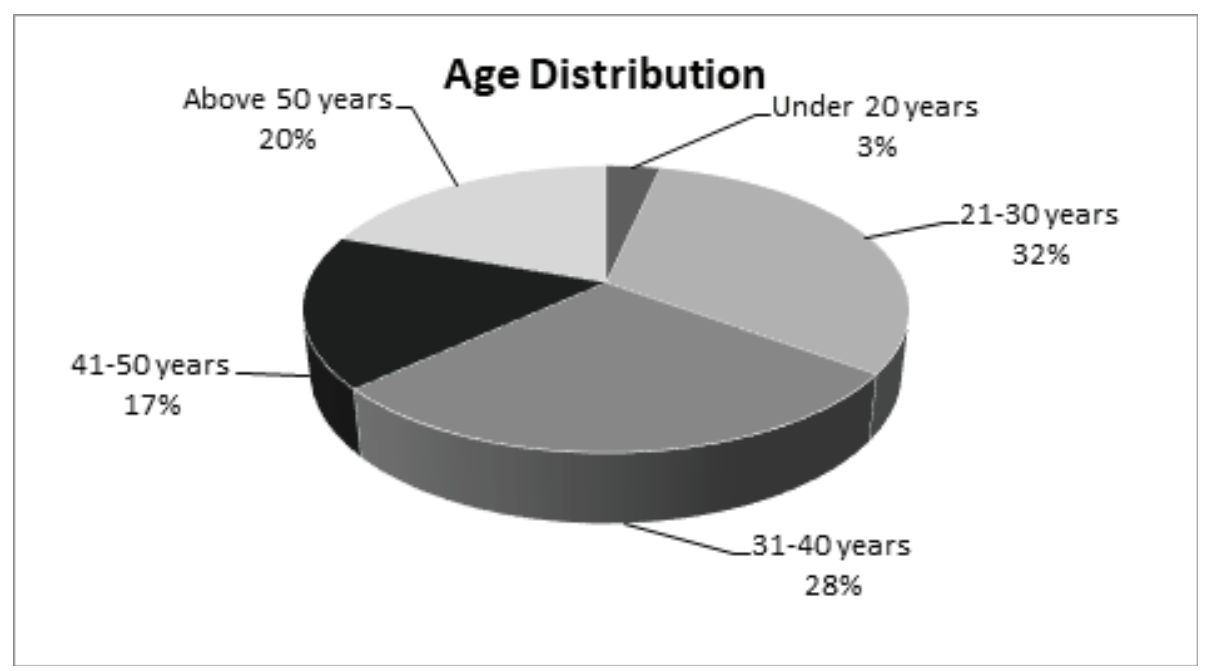

Figure 1: Age Distribution.

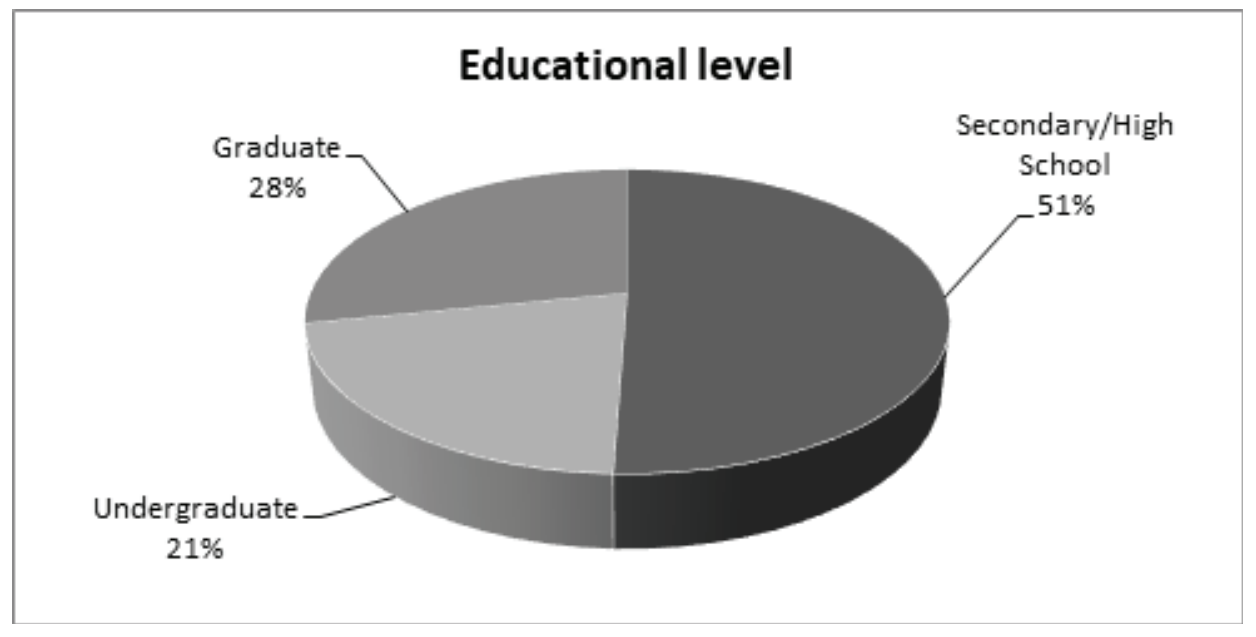

Figure 2: Educational Level.

Unemployment (16\%) and Community Support (15\%). Lastly, 10\% of the respondents associate Environmental Pollution with the industry's operations (Figure 3).

Next, respondent perceptions of the project's main contribution to the local community was examined. A total of $34 \%$ of respondents believe that the project's main contribution was the decrease of unemployment. Additionally, $29 \%$ of them responded "all of the above" (more specifically, they believe that the project decreased community unemployment, built gender equity, and increased the supply of fresh fruits and vegetables to the local community). Furthermore, $28 \%$ consider the main contribution to be the supply of fresh and vegetables to the local community and $9 \%$ the enhancement of gender equity. It is worth mentioning that the LAB Project, according to respondents, appears to have played a significant impact on community development (Figure 4).

In addition, participants were asked to evaluate the overall project. It should be noted that from the five possible answers, (Poor, Fair, Good, Very Good \& Excellent), 


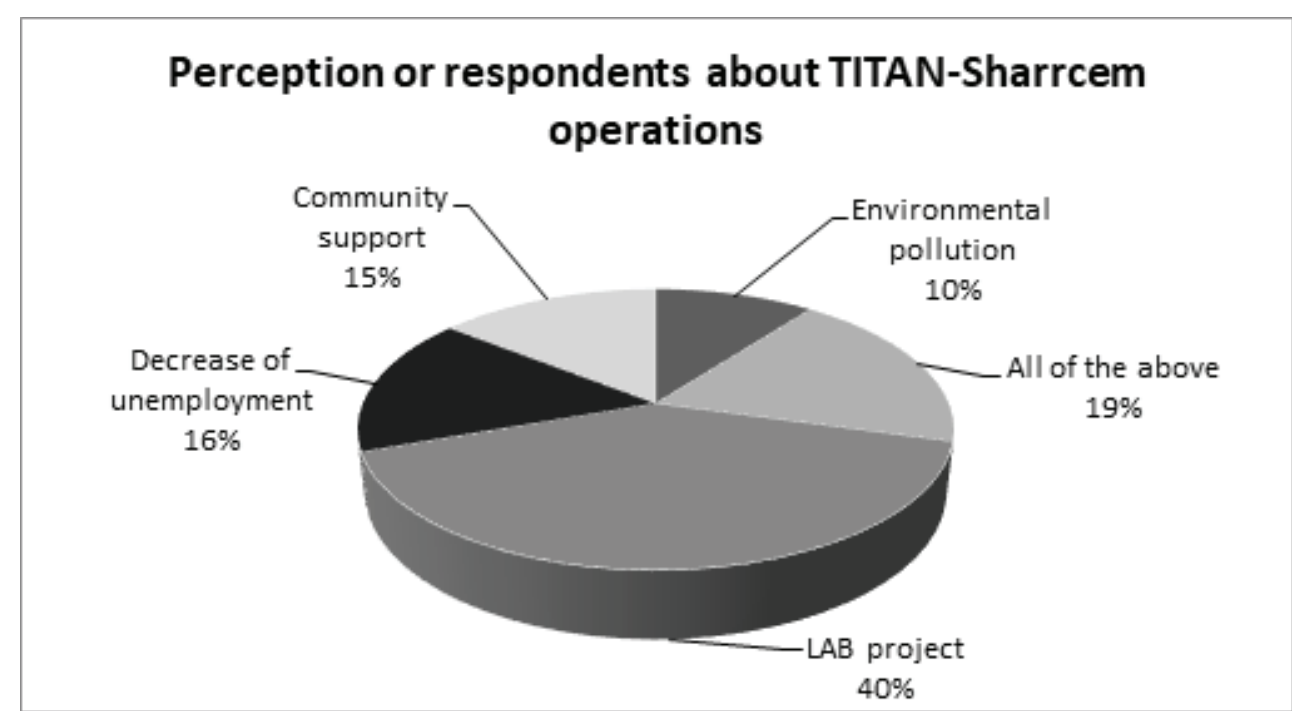

Figure 3: Perception of respondents about TITAN-Sharrcem operations.

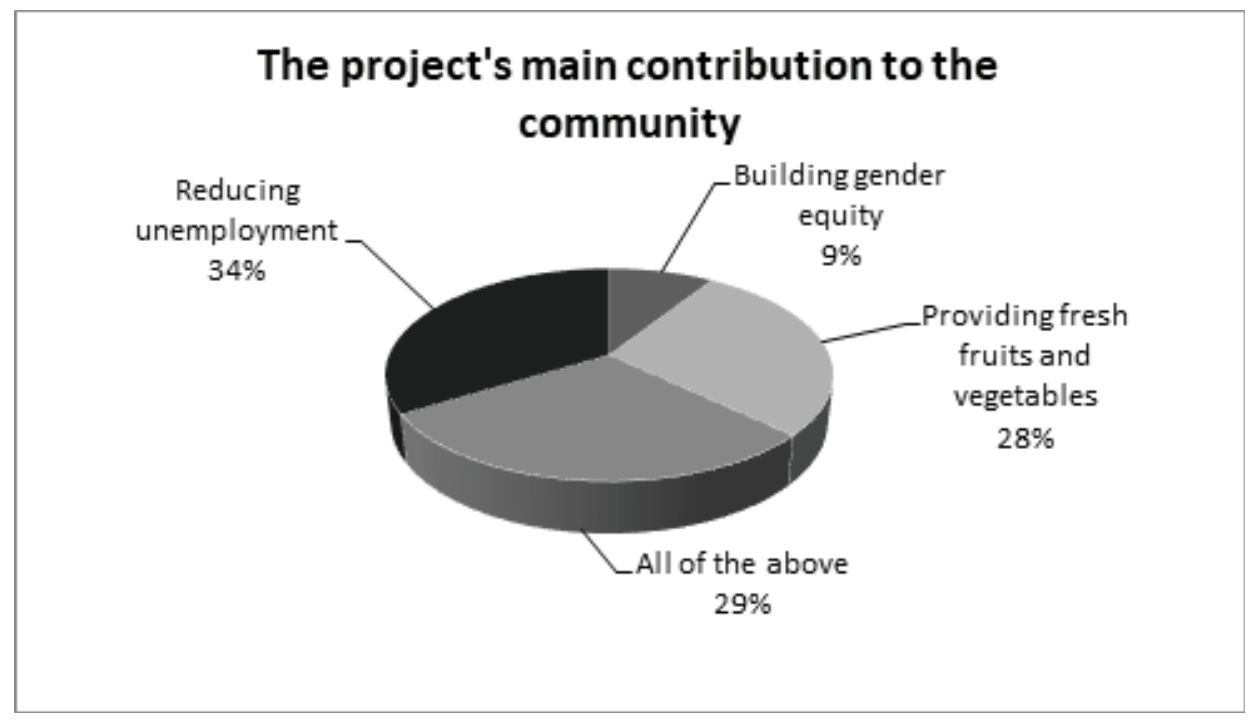

Figure 4: The project's main contribution to local community.

respondents selected only the three "positive" ones (there were no "poor" or "fair" responses). A total of $42 \%$ evaluated the project as very good, followed by $41 \%$ who evaluate it as excellent. Lastly, $17 \%$ of the respondents praised the LAB activities as being "good" (Figure 5).

Next, respondents were asked to evaluate the profitability of the start-up enterprises created through the LAB Project. Forty-nine percent (49\%) of the respondents believe that the profitability level is good, followed by $38 \%$ who believe that profitability is very good. On the other hand, $6 \%$ view it as excellent, $6 \%$ as fair, whereas only $1 \%$ perceives the profitability level of the start-ups as being poor (See Figure 6). 


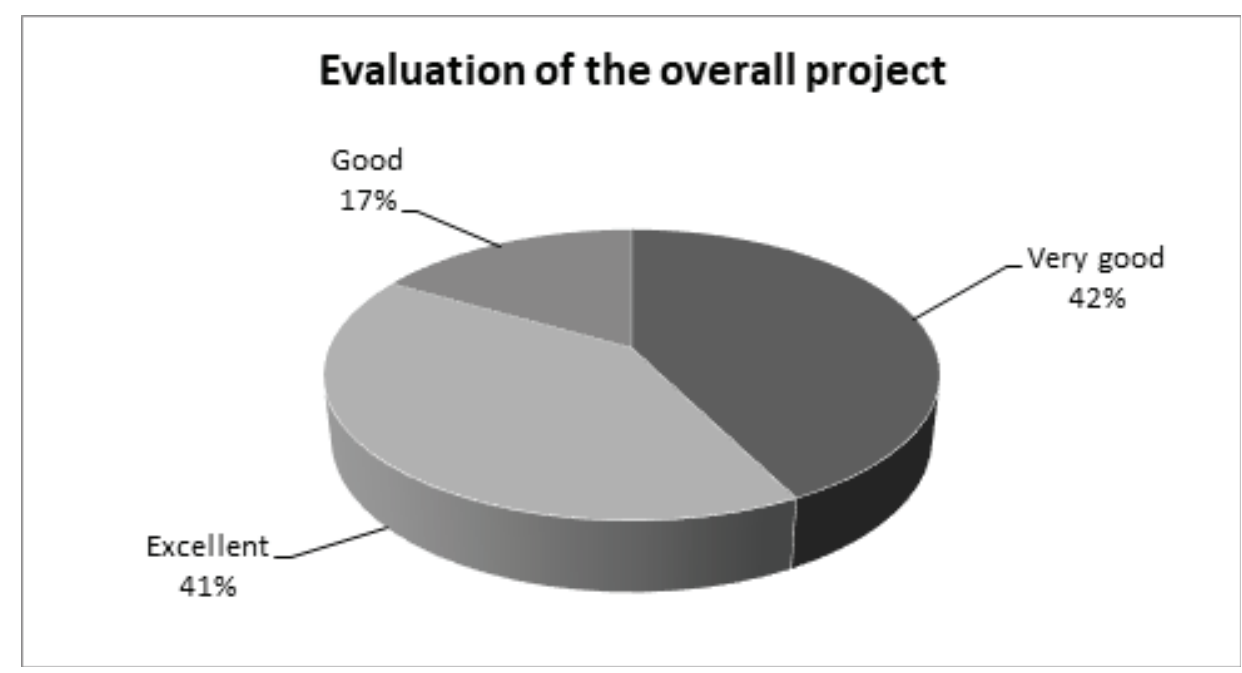

Figure 5: Evaluation of the overall project.

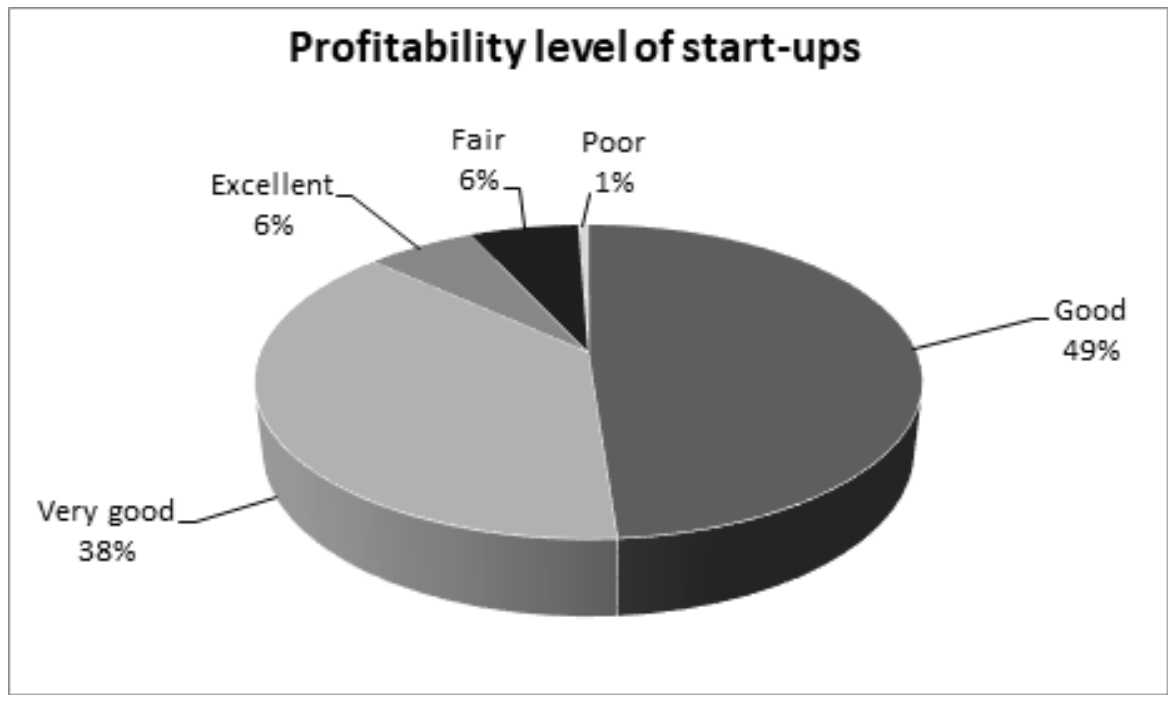

Figure 6: Profitability level of start-ups.

A key indicator of measuring the project's effectiveness was the farmers' ability to produce products that meet market quality standards. The quality of the products they produce is crucial long-term sustainability. In that regard, $90 \%$ of the respondents believe that the quality of the products meets market needs, thus, they appear satisfied with their quality. This is an indication of overall project effectiveness and success of activities implemented to support and train the farmers. However, $10 \%$ of the respondents believe that quality could be further improved with the assistance and collaboration of project experts (Figure 7).

As mentioned above, the LAB Project has had a significant impact on farmers and on community quality of life through income generation, a decrease in unemployment, the improvement in quality of products produced and consumed by the residents, etc. Figure 8 below depicts a precise evaluation of overall community perception of project 


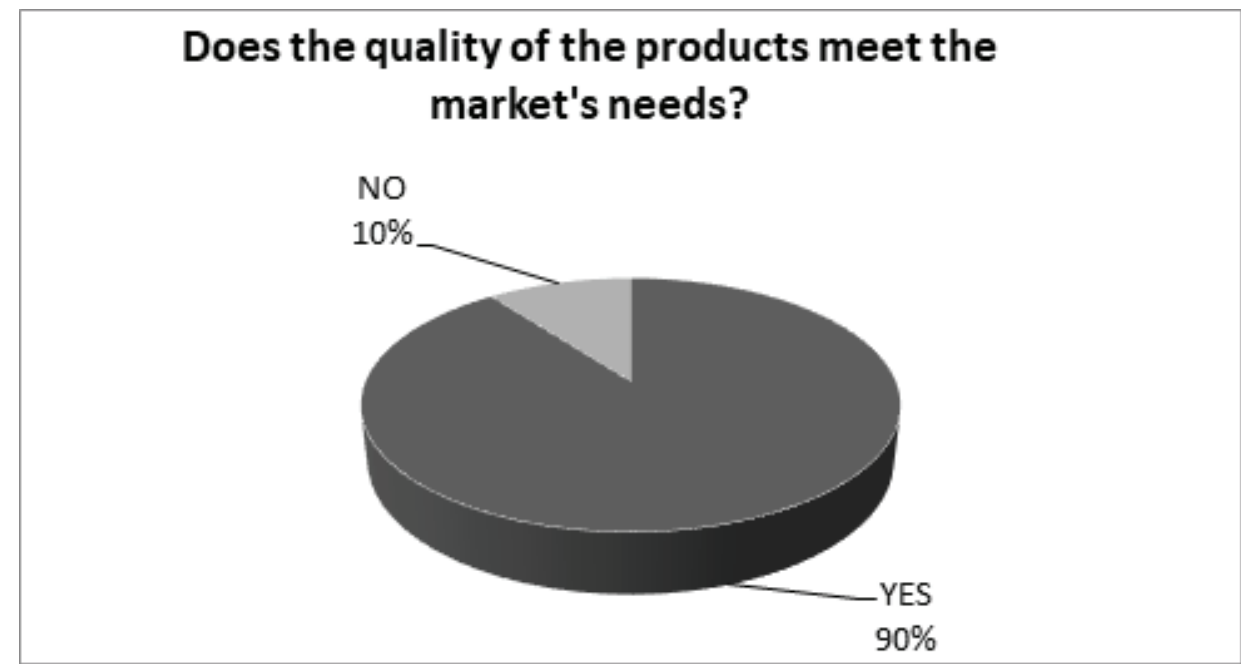

Figure 7: Does the quality of the products meet the market's needs?

impact. The responses to the question "if the project has affected the community's quality of life" indicate that $53 \%$ of the respondents believe that it has had a moderate effect, followed by $36 \%$ who answered that it had a major impact. On the other hand, $8 \%$ are neutral, while only a small percentage $(3 \%)$ responded that the project had no effect on the community. The results underline overall project effectiveness as $89 \%$ of the respondents consider the project to have positively affected the lives of local residents (Figure 8).

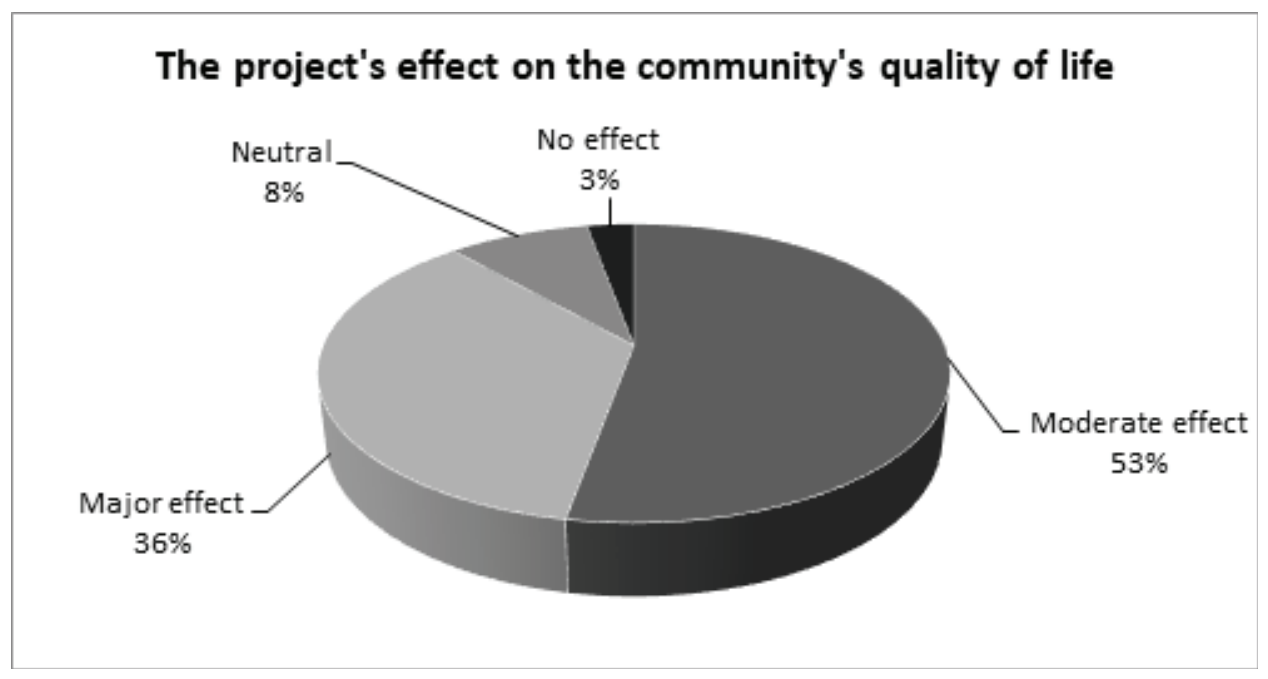

Figure 8: The project's effect on the community's quality of life.

\section{Discussion}

The objective of the LAB initiative is to address the socio-economic challenges faced by the community of Hani I Elezit. More specifically, it aims to contribute through financial 
and expertise support for the sustainable development of the community's agribusiness sector and to improve the local quality of life. This is different from the traditional CSR approach that focused on philanthropy [37, 38]. This is the company's most significant CSR initiative in the region. Respondent perception regarding the firm's operations in the region is largely (40\%) associated with the LAB project rather than other initiatives. Additionally, only $10 \%$ mentioned environmental issues as the core association with the TITAN--Sharrcem firm. This is worth noting, as the company produces cement and environmental matters were expected to be of major concern to local residents.

The LAB Project appears to have had an important positive impact on community development. More specifically, the perception of the local residents is that it has addressed specific key economic and social challenges faced by the community such as unemployment, gender equity, and the supply of fresh fruits and vegetables to the local community. These perceptions are in accordance with the view that companies should shift from the provision of infrastructure to local communities to CSR projects that build capacity and reduce poverty, which are of major concern to local communities in many instances [39].

Overall, respondents express a strongly positive attitude towards the project. Their responses reveal that there is no "controversy" about this ambitious plan and show positive feelings about project development priorities. The community's positive response can be partially attributed to the fact that investments in the agro-food sector were made after a sectoral analysis revealing its potential. The analysis was conducted by the firm with the assistance of external stakeholders. The responses imply that local population perception is that the firm is committed to community development through the development of an entrepreneurial culture. It should be noted, that the community's acceptance and consent is essential for overall project success.

The particularly positive responses indicate that the project has set the foundations of a sustainable economic development. The economic profitability of the enterprises established through the project enhances their continuation and viability. Importantly, these enterprises serve as a "best case example" for other community members to follow an "entrepreneurial path" and initiate business activities in the community. Finally, the positive results enhance community empowerment and engagement.

The quality of products is perceived to meet local market standards by the vast majority of the respondents. This result has two dimensions. Firstly, the improved quality of the products increases their competitiveness. As a result, higher economic returns for producers are anticipated. Secondly, there is an improvement in community quality of life, as healthier and safer fruits and vegetables are available to them. In regard to the 
improvement of local community quality of life, the largest percentage of respondents believe that the project had an overall positive impact. However, more than half of the respondents consider the impact to be moderate. Thus, efforts should be made to increase the impact on the general population.

According to Gilberthope and Banks [40], often CSR projects are designed and implemented based on values that are different from the local communities' perceptions on development. However, the empirical results of this study show that in the LAB Project case, both the firm's and the HIE residents' perceptions on sustainable development are aligned.

\section{Managerial Implications}

The findings of this research have a few important managerial implications for firms who aim to implement CSR strategies and to increase their positive impact on local societies. CSR initiatives are developed by companies in order to provide financial and non-financial support for the sustainable development of local communities and require their engagement and empowerment in order to be successful. Therefore, managers should concentrate on developing a trustful relationship between their companies and the local communities in order to gain from the benefits of cooperation. For this purpose, managers should facilitate communications with the local communities allowing the various stakeholders to learn about the company's intentions and to develop a deeper understanding among them and the company. Open exchange of information with the local communities through formal and informal channels of communication should be adopted by managers in order to efficiently resolve possible misunderstandings. Moreover, it should be noted that CSR initiatives, if designed and implemented appropriately, have the potential to lead to long-term mutual benefits for firms and local communities.

\section{Conclusion - Recommendations for Future Research}

Today, CSR has become an important tool for companies to increase their competitiveness. The LAB Project by TITAN--Sharrcem is a unique case in the environment of South East Europe. It demonstrates how firms, through CSR, can have an impact and build long-term relationships with the communities in which they operate. This study sought to explore the outcome of a CSR activity on rural development from the perspective of the local residents in Hani I Elezit, Kosovo, while also examining some of the benefits 
enjoyed by the residents as result of the project. The findings are rather important, as the focus is the community's perspective of CSR activities, which according to Mclennan and Banks [41], has received less attention from researchers compared to the businesses' perspectives. Additionally, this best practice can serve as a useful guideline for firms that want to engage in similar initiatives and successfully contribute to local communities' sustainable development.

The results reveal overall respondents' satisfaction and positive attitude towards the project and its impact on the local community. The project has benefited the local community and has set the foundations for sustainable development in the region's agricultural sector. This CSR initiative demonstrates the way firms can effectively develop strong ties with the local communities and simultaneously improve their overall public image. Efforts should be made to ensure maximum community engagement and empowerment. According to Idemudia [39], CSR initiatives implemented by MNCs would be successful only if they mutually benefit all parties involved and if they result to the development of a trustful relationship between the companies and the local communities.

This research is subject to certain limitations. First, it is a single case study in a specific country and, although this was not the intention, the generalization of results is not possible, considering the local cultural, political and economic particularities. Second, the perceptions of women and men were not presented separately. This is rather important considering the gender inequality issues in the country [36] and the considerable perceptual differences that might exist between the two genders.

The study sets the groundwork for a more detailed analysis of CSR initiatives in South East Europe. More specifically, an analysis of initiatives should be conducted in this region with similar characteristics of local communities, where the industry can play the role of 'enabler' for the sustainability of such communities. In addition, a longitudinal study containing a larger sample will more accurately depict local community perception. Researchers have underlined the need to further investigate the relationship between firms and local communities [29, 42]. It would be interesting to investigate ways to increase the effectiveness of CSR initiatives and their impact on local population. Furthermore, future studies on CSR initiatives in the same industry would allow for comparisons and for identification of best practices and could explore if this approach has similar implications in other industries. The LAB Project represents a truly interesting example of how companies can impact and build long-term relationships with the communities in which they operate. This specific project is one of 
the most comprehensive CSR initiatives implemented in Kosovo, regarding community involvement and its impact on the challenges faced by the local community.

\section{References}

[1] Jones, P., Comfort, D. \& Hillier, D. (2007). Marketing and corporate social responsibility within food stores. British Food Journal, vol. 109, no. 8, pp. 582--593.

[2] Badulescu, A., Badulescu, D., Saveanu, T. \& Hatos, R. (2018). The Relationship between Firm Size and Age, and Its Social Responsibility Actions-Focus on a Developing Country (Romania). Sustainability, vol. 10, no. 3, p. 805.

[3] Rangan, K., Chase, L. A. \& Karim, S. (2012). Why Every Company Needs a CSR Strategy and How to Build It. Harvard Business School, Working Paper no. 12-088, pp. 1--31.

[4] Chapple, W. \& Moon, K. (2005). Corporate Social Responsibility in Asia: a sevencountry study on CSR web site reporting", Business and Society, vol. 44, no. 4, pp. 415--441.

[5] Anon, n.d, 'Communication from the Commission concerning Corporate Social Responsibility: A business contribution to Sustainable Development' [Online] Available at: https://ec.europa.eu/europeaid/communication-commission-concerningcorporate-social-responsibility-business-contribution_en [Accessed on July 2019].

[6] Isa, S. M. (2012). Corporate Social Responsibility: What can we Learn from the Stakeholders? Procedia - Social and Behavioral Sciences. vol. 65 (ICIBSoS), pp. 327--337, doi: 10.1016/j.sbspro.2012.11.130.

[7] Spence, L. \& Bourlakis, M. (2009). The evolution from corporate social responsibility to supply chain responsibility: the case of Waitrose. Supply Chain Management: An International Journal, vol. 14, no. 4, pp. 291--302.

[8] D'Astous, A. \& Legendre, A. (2009). Understanding Consumers' Ethical Justifications: A Scale or Appraising Consumers' Reasons for Not Behaving Ethically. Journal of Business Ethics, vol. 87, no. 2, pp. 255--268.

[9] Abdolvand, M. \& Charsetad, P. (2013). Corporate social responsibility and brand equity in industrial marketing. International Journal of Academic Research in Business and Social Science, vol. 3, no. 9, pp. 273--284.

[10] Fatma, M., Rahman, Z. \& Khan, I. (2015). Building company reputation and brand equity through CSR: the mediating role of trust. International Journal of Bank Marketing, vol. 33, no. 6, pp. 840--856. 
[11] Friedrich, N., Heyder, M. \& Theuvsen, L. (2012). Sustainability management in agribusiness: Challenges, concepts, responsibilities and performance, in Proceedings of the 6th International European Forum on System Dynamics and Innovation in Food Networks, International Center for Food Chain and Network Research, University of Bonn, Germany, February 13-17, 2012, Innsbruck-Igls, Austria (No. 1020-2016-81734, p. 530).

[12] Moravcikova, K., Stefanikova, L'. \& Rypakova, M. (2015). CSR Reporting as an Important Tool of CSR Communication. Procedia Economics and Finance, vol. 26, no. 15 , pp. 332--338.

[13] Locke, R. M. (2002). The promise and perils of globalization: The case of Nike. Industrial Performance Center, (July), pp. 1--36. doi: 10.1108/13598540710759745.

[14] Harrison, A. \& Scorse, J. (2004). The Nike effect: Anti-sweatshop activists and labor market outcomes in Indonesia. UC Berkeley, (March), pp. 1--48. Available at: http://economics.yale.edu/sites/default/files/files/Workshops-Seminars/ Development/harrison-040322.pdf.

[15] Šontaitè-Petkevičienè, M. (2015). CSR Reasons, Practices and Impact to Corporate Reputation. Procedia - Social and Behavioral Sciences, vol. 213, pp. 503--508.

[16] Banerjee, S. B. (2014). A critical perspective on corporate social responsibility: Towards a global governance framework. Critical Perspectives on International Business, vol. 10, no. 1/2, pp. 84--95.

[17] Eliasson, M. \& Smajovic, S. (2009). CSR Communication \& SMEs. Master Thesis within Entrepreneurship, Management \& Marketing, Jonkoping International Business School, pp. 6--47.

[18] Anon, n.d, 'TITAN Integrated Annual Report 2018' [Online] Available at: http:// integratedreport2018.titan.gr/ [Accessed on June 2019],

[19] Anon., n.d, 'Corporate Social Responsibility and Sustainability Report 2013', TITAN - Sharrcem, [Online] Available at: http://sharrcem.com/wp-content/uploads/2014/12/ CSR-Report-2013-English.pdf [Accessed on April 2018].

[20] Vergos, V. \& Shabanaj, H. (2017). Sustainable Community Development through Innovative Entrepreneurial Actions. [online] Esee2017.maich.gr. Available at: http:// esee2017.maich.gr/uploads/attachments/58/Vergos___Shabanaj.pdf [Accessed on June 2019].

[21] Anon., n.d, 'Kosovo Agency of Statistics' 2016 \& 2017, ask, [Online] Available at: http://ask.rks-gov.net/en/kosovo-agency-of-statistics/economy [Accessed on April 2018]. 
[22] Anon., n.d, 'Corporate Social Responsibility and Sustainability Report 2014' TITAN - Sharrcem, [Online] Available at: http://sharrcem.com/wp-content/uploads/2016/02/ Sharrcem-CSR-Report-2014-ENGLISH.pdf [Accessed on April 2018].

[23] Kepore, K. P. \& Imbun, B. Y. (2011). Mining and stakeholder engagement discourse in a Papua New Guinea mine. Corporate Social Responsibility and Environmental Management, vol. 18, no. 4, pp. 220--233.

[24] Anon., n.d, 'Project - Laboratory for Business Activities' Report May - November 2014.

[25] Anon., n.d, 'Project - Laboratory for Business Activities' Report January - December 2018.

[26] Anon., n.d, 'Project - Laboratory for Business Activities' Report January - December 2015.

[27] Anon., n.d, 'Project - Laboratory for Business Activities' Report January - December 2016.

[28] Anon., n.d, 'Project - Laboratory for Business Activities' Report January - December 2017.

[29] Ismail, M., Alias, S. N. \& Mohd Rasdi, R. (2015). Community as stakeholder of the corporate social responsibility programme in Malaysia: outcomes in community development. Social Responsibility Journal, vol. 11, no. 1, pp. 109--130.

[30] Wisdom, J. P., Cavaleri, M. A., Onwvuegbuzie, A. J. \& Green A. (2011). Methodological Reporting in Qualitative, Quantitative, and Mixed Methods Health Services Research Articles. Health Services Research, vol. 47, no. 2, pp. 721--745.

[31] Collis, J. \& Hussey, R. (2009). Business research: A practical guide for undergraduate and postgraduate students, 3rd edition, Palgrave Macmillan, UK.

[32] Yilmaz, K. (2013). Comparison of Quantitative and Qualitative Research Traditions: epistemological, theoretical, and methodological differences. European Journal of Education, vol. 48, no. 2, pp. 311--325.

[33] Collis, J. \& Hussey, R. (2009). Business research: A practical guide for undergraduate and postgraduate students, 3rd edition, UK: Palgrave Macmillan.

[34] Joshi, A., Kale, S., Chandel, S. \& Pal, D. K. (2015). Likert Scale: Explored and Explained. British Journal of Applied Science \& Technology, vol. 7, no. 4, pp. 396--403.

[35] Anon., n.d, 'City population of Hani I Elezit, Kosovo' [Online] Available at: http://www. citypopulation.info/php/kosovo-admin.php?adm2id=33[Accessed on April 2018].

[36] Haug, H. K. (2015). Gender equality and inequality in Kosovo, in Gender (In) equality and Gender Politics in Southeastern Europe, Palgrave Macmillan, London, pp. 147-168. 
[37] Secchi, D. (2007). Utilitarian, managerial and relational theories of corporate social responsibility. International Journal of Management Reviews, vol. 9, no. 4, pp. 347-373.

[38] Lee, M. D. P. (2008). A review of the theories of corporate social responsibility: Its evolutionary path and the road ahead. International Journal of Management Reviews, vol. 10, no. 1, pp. 53--73.

[39] Idemudia, U. (2007). Community perceptions and expectations: reinventing the wheels of corporate social responsibility practices in the Nigerian oil industry. Business and Society Review, vol. 112, no. 3, pp. 369--405.

[40] Gilberthorpe, E. \& Banks, G. (2012). Development on whose terms?: CSR discourse and social realities in Papua New Guinea's extractive industries sector. Resources Policy, vol. 37, no. 2, pp. 185-193.

[41] McLennan, S. \& Banks, G. (2019). Reversing the lens: Why corporate social responsibility is not community development. Corporate Social Responsibility and Environmental Management, vol. 26, no. 1, pp. 117--126.

[42] Margolis, J. D. \& Walsh, J. P. (2001). People and profits?: The search for a link between a company's social and financial performance. New York, Psychology Press. 